\title{
Catalytic epoxidation of cyclic vinylsilanes by ruthenium(II) complexes under aerobic conditions
}

\author{
Abirami Srikanth, ${ }^{\mathrm{a}, \mathrm{b}}$ Gopalpur Nagendrappa ${ }^{\mathrm{b}}$ and Srinivasan Chandrasekaran ${ }^{\mathrm{a}, *}$ \\ ${ }^{a}$ Department of Organic Chemistry, Indian Institute of Science, C. V. Raman Avenue, Bangalore 560012, India \\ ${ }^{\mathrm{b}}$ Department of Chemistry, Bangalore University, Central College campus, Bangalore 560001, India
}

Received 13 May 2003; revised 1 July 2003; accepted 30 July 2003

\begin{abstract}
A new methodology has been developed for the catalytic epoxidation of cyclic vinylsilanes using a ruthenium(II) bisoxazoline complex 2 with molecular oxygen. An attempt has been made to understand the role of $-\mathrm{SiMe}_{3}$ group on the rate of epoxidation process. (C) 2003 Elsevier Ltd. All rights reserved.
\end{abstract}

\section{Introduction}

Metal catalysed epoxidation of alkenes constitutes an important tool in organic synthesis. ${ }^{1}$ The importance of the epoxidation reaction lies in the fact that the formed epoxides can be converted into a variety of useful products. It is also attractive in asymmetric synthesis because it can lead to two asymmetric centres in one step. Transition-metal complexes as catalysts for epoxidation have been receiving increased attention during the past three decades. ${ }^{2}$ The need for functionalisation of lower alkenes formed as by-products in the manufacture of gasoline, the need for partial selective oxidation and the need for the preparation of compounds with a specific spatial structure are some of the reasons for the rapid growth in this field. Today a number of transition metal complexes are available which use a variety of oxygen sources for the epoxidation. ${ }^{3}$

Ruthenium complexes are good epoxidation catalysts, ${ }^{4}$ which form high valent oxo-ruthenium species as active intermediates in the oxygen transfer process. Ruthenium complexes with nitrogen based ligands ${ }^{5}$ have been extensively studied in recent years to develop new catalysts with better selectivity and several co-oxidants have been employed to get the best results. Clearly, the ideal oxidant would be molecular oxygen since it is least expensive and also environmental friendly. Recently we reported a novel ruthenium(II) bisoxazoline complex $\mathbf{1}^{6}$ as a catalyst for a highly stereo, regio and diastereoselective epoxidation of simple olefins using molecular oxygen. The choice of bisoxazolines as ligands was natural owing to the fact that in combination with ruthenium, they form complexes analogous to Schiff's base derived complexes. Additionally, the

Keywords: epoxidation; ruthenium; vinylsilanes; molecular oxygen.

* Corresponding author. Tel.: +91-80-293-2404; fax: +91-80-360-0529; e-mail: scn@orgchem.iisc.ernet.in ease of preparation from readily available starting materials and the versatility of ligand design have made them attractive to organic chemists.

The synthesis of ruthenium complexes $\mathbf{1}$ and $\mathbf{2}$ can be accomplished by treating two equivalents of the corresponding bisoxazoline with trans tetrakis(acetonitrile)dichloro ruthenium in refluxing dichloroethane ${ }^{6}$ (Fig. 1). The catalyst $\mathbf{2}$ was preferred over $\mathbf{1}$ for a study of catalytic activity due to its better solubility in common organic solvents although the catalytic activity of both $\mathbf{1}$ and $\mathbf{2}$ was almost the same. In an attempt to expand the scope of this new methodology, we present the results of our investigations on the aerobic epoxidation of cyclic vinylsilanes with ruthenium catalyst, 2 .

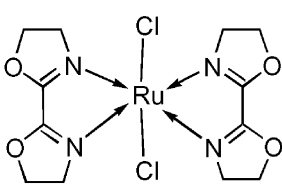

1

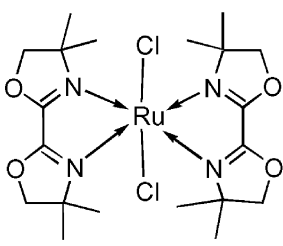

2
Figure 1.

\section{Results and discussion}

Epoxidation of cyclic vinylsilanes furnish $\alpha, \beta$-epoxy silanes, ${ }^{7}$ a class of compounds of considerable interest to the organic chemists. The presence of the trialkylsilyl group provides regioselective control in the opening of epoxide by a variety of nucleophiles. ${ }^{8}$ Also it can be removed under extremely mild conditions to afford epoxides ${ }^{9}$ which in some cases are difficult targets by direct synthetic transformations. Further, the $\alpha, \beta$-epoxy silanes can be used as "vinyl cation" equivalents ${ }^{10}$ which are very useful 


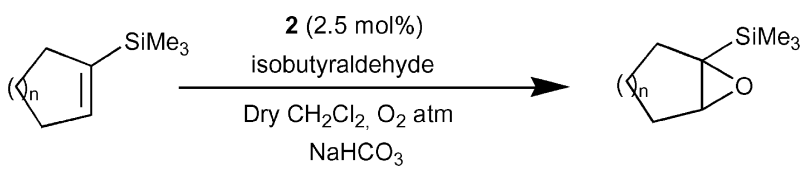

$n=1,2,3,4,8$

Scheme 1.

synthetic intermediates. They can be readily transformed into $\beta$-hydroxy silanes ${ }^{11}$ and also into $\alpha$-hydroxy carbonyl compounds. The cyclic vinylsilanes needed for the present study were readily synthesized from the cyclic vinyl halides and chlorotrimethylsilane by the Wurtz type coupling methodology. ${ }^{12}$

A typical aerobic epoxidation of cyclic vinylsilane involves treatment of the vinylsilane $(1 \mathrm{mmol})$ with the catalyst 2
$(2.5 \mathrm{~mol} \%)$ and isobutyraldehyde $(1.5 \mathrm{mmol})$ under an oxygen atmosphere in dichloromethane at room temperature ( $\left.28^{\circ} \mathrm{C}, 4.5-20 \mathrm{~h}\right)$. Solid $\mathrm{NaHCO}_{3}$ was added to buffer the isobutyric acid formed during the reaction (Scheme 1).

The results of epoxidation of a number of cyclic vinylsilanes are summarized in Table 1. All the cyclic vinylsilanes except 5 produced the corresponding $\alpha, \beta$-epoxysilanes in moderate to high yields (62-94\%) along with $8-10 \%$ of the corresponding 3-trimethylsilyl-2-ene-1-ones. In the case of 5, we observe the formation of the silylated enones to the extent of $26 \%$. Similar results have been documented in the literature using dimethyldioxirane as the oxidizing agent. ${ }^{13}$ Interestingly in the reaction of 11, the epoxide $\mathbf{1 2}$ is the exclusive product. Similarly in the reaction of $\mathbf{9}$ with catalyst 2, the epoxide $\mathbf{1 0}$ is the sole product formed. An interesting feature of this methodology is that the primary

Table 1. Epoxidation of cyclic vinylsilanes using 2 under aerobic conditions at room temperature $\left(28^{\circ} \mathrm{C}\right)$

\begin{tabular}{|c|c|c|c|c|}
\hline Entry & Substrate & Time (h) & Yield $^{\mathrm{g}}(\text { Conversion })^{\mathrm{d}}$ & $\operatorname{Product}(\mathrm{s})^{\mathrm{e}}$ \\
\hline 1 & & 7 & $72(98)$ & $4^{\mathrm{a}}$ \\
\hline 2 & & 11 & $56(90)$ & $6^{\mathrm{b}}$ \\
\hline 3 & & 14 & $65(90)$ & $8^{a}$ \\
\hline 4 & & 8 & $80(97)$ & 10 \\
\hline $\begin{array}{l}5 \\
6\end{array}$ & & $\begin{array}{l}4.5 \\
20\end{array}$ & $\begin{array}{l}92(98) \\
73(88)\end{array}$ & \\
\hline 7 & & 6.5 & $80(90)$ & \\
\hline 8 & & 17 & $70(95)$ & \\
\hline
\end{tabular}

${ }^{a}$ In the case of $\mathbf{3}, \mathbf{7}, \mathbf{1 3}$ and $\mathbf{1 5}, 8-10 \%$ of silylated enones (allylic oxidation) were also isolated. ${ }^{\mathrm{b}}$ In the case of $\mathbf{5}, 26 \%$ of diastereomeric mixture of the silylated enones was formed. ${ }^{\mathrm{c}}$ The reaction was performed at $60^{\circ} \mathrm{C}$. ${ }^{\mathrm{d}}$ The conversion was determined by means of gas chromatography using a SE 30 capillary column. ${ }^{\mathrm{e}}$ All products exhibited spectroscopic data identical to that reported in the literature. ${ }^{\mathrm{f}} \mathrm{A}$ mixture of $42 \%$ cis and $58 \%$ trans. ${ }^{\mathrm{g}}$ Refers to isolated yields. 


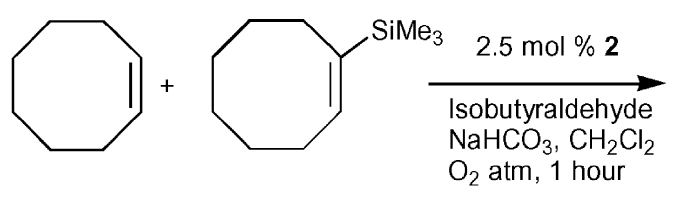

$\mathrm{O}_{2}$ atm, 1 hour

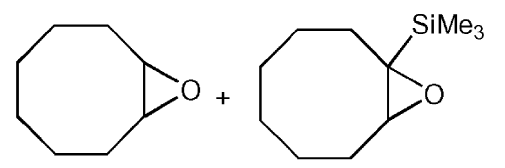

$[5: 1]$

Scheme 2.

product of allylic oxidation, i.e. the allylic alcohol was not detected even in trace amounts and no desilylation was observed in any of the substrates indicating the mildness of the procedure.

The optimal loading of the catalyst 2 was found to be $2.5 \mathrm{~mol} \%$ with respect to the alkene. However, the reaction takes place even with 1 mol\% of catalyst 2 with longer reaction time. When 1-trimethylsilyl cyclooctene (9) was subjected to epoxidation using $1 \mathrm{mmol}$ of the catalyst, the reaction went to completion in $12 \mathrm{~h}$ whereas with $2.5 \mathrm{~mol} \%$ of 2 , the same conversion was accomplished in about $8 \mathrm{~h}$. Next, the effect of temperature on the reaction was also examined. With vinylsilane $\mathbf{9}$ as the substrate, the reaction with 2 was completed in $8 \mathrm{~h}\left(28^{\circ} \mathrm{C}\right.$, entry 4$)$. However, when the reaction was performed at $60^{\circ} \mathrm{C}$, keeping other experimental conditions identical, the reaction went to completion in $4.5 \mathrm{~h}$ (entry $5,94 \%$ ). A further increase in temperature seems to be detrimental resulting in a mixture of products.

To understand the effect of the trimethylsilyl substituent at the double bond in the rate of the transition metal catalyzed aerobic epoxidation, a competitive experiment between trimethylsilyl cyclooctene and cyclooctene was performed.

Treatment of cyclooctene and silylsubstituted cyclooctene 9 (1:1) with the ruthenium catalyst 2 (2.5 mol\%, $\mathrm{CH}_{2} \mathrm{Cl}_{2}$, $28^{\circ} \mathrm{C}, 1 \mathrm{~h}$ ), it was found that cyclooctene was oxidized faster compared to the corresponding silyl substituted alkene, 9 (Scheme 2). The relative ratio of consumption of the two olefins was found to be 84:16, after a period of $1 \mathrm{~h}$. This is in contrast to the results of epoxidation by peracids wherein the vinylsilanes were found to be more reactive than their unsilylated analogues. ${ }^{14}$ The relative sluggishness of the vinylsilanes can be attributed to the steric hindrance exerted by the trimethylsilyl substituent for the approach of the relatively large sized ruthenium catalyst $\mathbf{2}$ during the oxygen transfer process. The difference in reactivity seem to indicate that steric factor is more important than the electronic factor in the present case of the transition metal based epoxidation process.

The mechanism of the reaction probably involves high valent ruthenium-oxo species during the oxo transfer process to the alkene. Although perisobutyric acid is known to be formed ${ }^{15}$ under the given reaction conditions, it is more likely that the active oxo transfer step involves the ruthenium-oxo species. Several attempts towards isolation of these intermediates remain futile. Since the rutheniumbisoxazoline catalyst $\mathbf{2}$ is analogous to ruthenium porphyrins, a similar mechanistic pathway involving the formation of $\mathrm{Ru}^{2+}, \mathrm{Ru}^{4+}$ and $\mathrm{Ru}^{6+}$ oxidation states has been proposed (Scheme 3). ${ }^{16}$

\section{Conclusion}

In summary, we have reported a new methodology using a novel ruthenium(II) complex 2 for the catalytic epoxidation of cyclic vinylsilanes under effectively neutral conditions with molecular oxygen and isobutyraldehyde as a sacrificial reductant.

\section{Experimental}

\subsection{General}

4.1.1. Preparation of the ruthenium complex $1 .^{6} \mathrm{~A}$ solution of trans-tetrakis(acetonitrile)dichlororuthenium ${ }^{17}$ $(0.336 \mathrm{~g}, 1 \mathrm{mmol})$ and 4,4,4',4'-tetrahydro-2-2'-bisoxazole $(0.308 \mathrm{~g}, 2.2 \mathrm{mmol})$ was refluxed in dry ethanol $(10 \mathrm{~mL})$ for $6 \mathrm{~h}$ under nitrogen. The red solution was concentrated to a minimum volume $(1 \mathrm{~mL})$ under reduced pressure and the red solid was precipitated by addition of dry ether $(15 \mathrm{~mL})$. The solid was collected by filtration through a sintered funnel under nitrogen atmosphere. Recrystallization of the solid from dichloromethane/diethyl ether (1:1) gave the

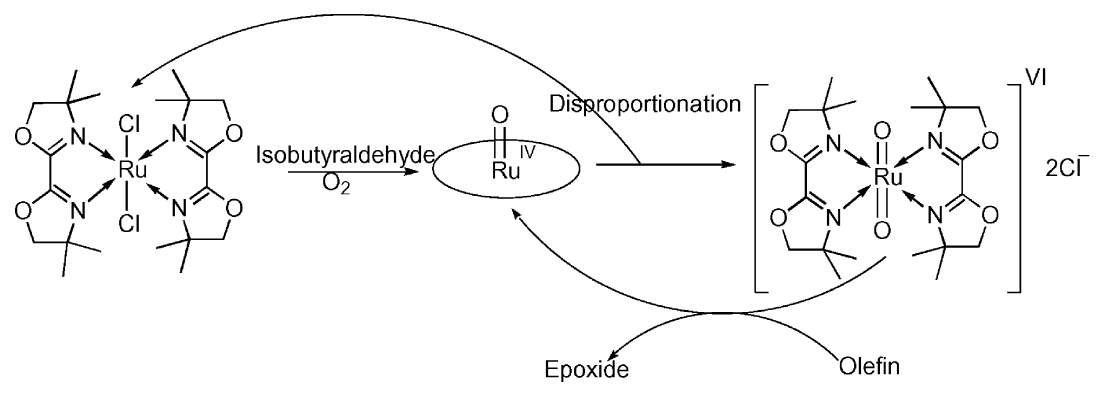


complex, $\mathbf{1}$ as a dark red powdery solid, which was dried under vacuum for $2 \mathrm{~h}$ and stored in a desiccator.

Yield 0.380 g, $82 \%$. Mp: $280-281^{\circ} \mathrm{C}$; FT-IR (Nujol): 2950 , $1610,335 \mathrm{~cm}^{-1} ;{ }^{1} \mathrm{H}$ NMR $\left(300 \mathrm{MHz}, \mathrm{CDCl}_{3}\right): \delta 3.49(8 \mathrm{H}$, $\mathrm{m}), 3.79(8 \mathrm{H}, \mathrm{m}) ;{ }^{13} \mathrm{C} \mathrm{NMR}\left(\mathrm{D}_{2} \mathrm{O}\right): \delta$ 53.6, 68.8, 155.7; Mass (MALDI): $453\left(\mathrm{M}^{+}+1\right)$; UV $\left(\lambda_{\max }\right)(\mathrm{MeOH}): 222$ (1.98), 467 (0.81); Elemental Analysis: calcd for $\mathrm{C}_{12} \mathrm{H}_{16} \mathrm{Cl}_{2} \mathrm{~N}_{4} \mathrm{O}_{4} \mathrm{Ru}$ (C 31.86, H 3.56, N 12.38); Found (C 31.81, H 3.48, N, 12.40).

4.1.2. Preparation of the ruthenium complex 2. A solution of trans-tetrakis(acetonitrile)dichlororuthenium (0.336 g, $1 \mathrm{mmol})$ and 4,4,4', $4^{\prime}$-tetramethyl-2,2'-bisoxazole $(0.392 \mathrm{~g}, 2 \mathrm{mmol})$ was refluxed in dry dichloroethane $(10 \mathrm{~mL})$ for $8 \mathrm{~h}$ under $\mathrm{N}_{2}$ atmosphere. The reaction mixture was concentrated to half its volume and then addition of dry ether $(15 \mathrm{~mL})$ precipitated the complex. The reddish brown complex was collected by filtration through a sintered funnel. The solid was washed with dry ether and dried under high vacuum for $3 \mathrm{~h}$. Recrystallization from dichloromethane/diethyl ether (1:1) gave the ruthenium complex 2 as a brownish red powder, which can be stored in a desiccator indefinitely.

Yield $0.401 \mathrm{~g}, 71 \%$. FT-IR ( $\left.\mathrm{cm}^{-1}\right)(\mathrm{KBr}): 3126$ (br), 1618, 1507, 1400, 1207, 751; ${ }^{1} \mathrm{H} \mathrm{NMR}\left(\mathrm{CDCl}_{3}, 300 \mathrm{MHz}\right): \delta 1.36$ $(24 \mathrm{H}, \mathrm{s}), 4.12(8 \mathrm{H}, \mathrm{s}) ;{ }^{13} \mathrm{C} \mathrm{NMR}\left(\mathrm{CDCl}_{3}, 75 \mathrm{MHz}\right): \delta 27.9$, 68.2, 79.6, 153.1; Mass (MALDI): $564\left(\mathrm{M}^{+}\right)$; UV $\left(\lambda_{\max }\right)$ $\left(\mathrm{CHCl}_{3}\right): 325$ (2.02), 383 (2.90), 468 (1.57), 641 (0.45); Elemental Analysis: calcd for $\mathrm{C}_{20} \mathrm{H}_{32} \mathrm{~N}_{4} \mathrm{O}_{4} \mathrm{ClRu} \cdot 2 \mathrm{H}_{2} \mathrm{O}(\mathrm{C}$ 39.93, H 5.99, N 9.32); Found (C 40.45, H 5.94, N 9.08).

\subsection{General procedure for the epoxidation of cyclic vinylsilanes}

To a magnetically stirred solution of the cyclic vinylsilane ( $1 \mathrm{mmol})$ in dry dichloromethane $(4 \mathrm{~mL})$ was added ruthenium complex $2(0.014 \mathrm{~g}, 2.5 \mathrm{~mol} \%)$, isobutyraldehyde $(0.18 \mathrm{~mL}, 1.5 \mathrm{mmol})$ and solid sodium bicarbonate $(0.168 \mathrm{~g}, 1.5 \mathrm{mmol})$. The resulting homogenous solution was stirred at room temperature under an atmosphere of oxygen for $7-20 \mathrm{~h}$. The progress of the reaction was monitored by following the disappearance of the starting olefin.

The reaction mixture was diluted with diethyl ether $(25 \mathrm{~mL})$ and was filtered through a pad of Celite. The clear filtrate was washed with water $(2 \times 15 \mathrm{~mL})$ and saturated brine solution $(20 \mathrm{~mL})$ and finally dried over anhydrous $\mathrm{Na}_{2} \mathrm{SO}_{4}$. After removal of the solvent on a rotary evaporator, the crude product was purified by column chromatography on silica gel using 1-2\% ethylacetate-hexanes. The pure epoxysilanes gave physical constants and spectroscopic data concordant with the literature values.

4.2.1. Trimethyl(6-oxa-bicyclo[3.1.0]hex-1-yl)silane $4 .^{18}$ Colourless liquid. Purified by column chromatography on silica gel (1\% ethylacetate-hexanes). Yield $0.116 \mathrm{~g}, 72 \%$; bp: $62-65^{\circ} \mathrm{C} / 45 \mathrm{~mm}$ (lit., ${ }^{18} \mathrm{bp}: 65^{\circ} \mathrm{C} / 50 \mathrm{~mm}$ ).

4.2.2. Trimethyl(7-oxa-bicyclo[4.1.0]hept-1-yl)silane $6{ }^{19}$ Colourless liquid. Purified by column chromatography on silica gel (2\% ethylacetate-hexanes). Yield: $0.098 \mathrm{~g}, 56 \%$; bp: $90-93^{\circ} \mathrm{C} / 30 \mathrm{~mm}$ (lit., ${ }^{19} \mathrm{bp}: 112-114^{\circ} \mathrm{C} / 73 \mathrm{~mm}$ ).

4.2.3. Trimethyl(8-oxa-bicyclo[5.1.0]oct-1-yl)silane 8. $^{18}$ Colourless liquid. Purified by column chromatography on silica gel (2\% ethylacetate-hexanes). Yield: $0.123 \mathrm{~g}, 65 \%$; bp: $84-86^{\circ} \mathrm{C} / 10 \mathrm{~mm}$ (lit., ${ }^{18} \mathrm{bp}: 77^{\circ} \mathrm{C} / 5 \mathrm{~mm}$ ).

4.2.4. Trimethyl(9-oxa-bicyclo[6.1.0]non-1-yl)silane 10. ${ }^{19}$ Colourless liquid. Purified by column chromatography on silica gel (1\% ethylacetate-hexanes). Yield: $0.163 \mathrm{~g}$, $80 \%$; bp: $58-60^{\circ} \mathrm{C} / 0.5 \mathrm{~mm}$ (lit., ${ }^{19} \mathrm{bp}: 52-54^{\circ} \mathrm{C} / 0.5 \mathrm{~mm}$ ).

4.2.5. Trimethyl(3-oxa-tricyclo[2.2.1.0 $\left.{ }^{2,4}\right]$ octan-2-yl)silane 12. ${ }^{20}$ Colourless liquid. Purified by column chromatography on silica gel ( $2 \%$ ethylacetate-hexanes). Yield: $0.133 \mathrm{~g}, 73 \%$; bp: $82-88^{\circ} \mathrm{C} / 10 \mathrm{~mm}$ (lit. ${ }^{20} \mathrm{bp}: 82-85^{\circ} \mathrm{C} /$ $10 \mathrm{~mm}) ;{ }^{1} \mathrm{H}$ NMR $\left(\mathrm{CDCl}_{3}, 300 \mathrm{MHz}\right): \delta 0.13(9 \mathrm{H}, \mathrm{s}), 1.0-$ $1.52(6 \mathrm{H}, \mathrm{m}$, complex), $2.37(1 \mathrm{H}, \mathrm{m}), 2.47(1 \mathrm{H}, \mathrm{m}), 3.04$ $(1 \mathrm{H}, \mathrm{s})$.

4.2.6. Trimethyl(3-oxa-tricyclo[4.2.1.0 $\left.{ }^{2,4}\right]$ non-2-yl)silane 14. ${ }^{21}$ Colourless liquid. Purified by column chromatography on silica gel ( $2 \%$ ethylacetate-hexanes). Yield: $0.157 \mathrm{~g}$, 80\%; bp: $65-67^{\circ} \mathrm{C} / 7 \mathrm{~mm} ;{ }^{1} \mathrm{H} \mathrm{NMR}\left(\mathrm{CDCl}_{3}, 300 \mathrm{MHz}\right): \delta$ $0.03(9 \mathrm{H}, \mathrm{s}), 1.0-1.08(1 \mathrm{H}, \mathrm{m}), 1.16-1.34(2 \mathrm{H}, \mathrm{m}), 1.53-$ $2.01(6 \mathrm{H}, \mathrm{m}), 2.47(1 \mathrm{H}, \mathrm{m}), 2.83(1 \mathrm{H}, \mathrm{d}, J=3.6 \mathrm{~Hz}) ;{ }^{13} \mathrm{C}$ NMR $\left(\mathrm{CDCl}_{3}, 75 \mathrm{MHz}\right): \delta-4.4,26.5,29.5,30.4,32.0$, 34.4, 35.2, 51.7, 60.1; Mass: $m / z 196\left(\mathrm{M}^{+}\right)$.

4.2.7. Trimethyl(13-oxa-bicyclo[10.1.0]tridecan-1-yl)silane 16. ${ }^{18}$ Colourless liquid. Purified by column chromatography on silica gel (2\% ethylacetate-hexanes). Yield $0.178 \mathrm{~g}, 70 \%$; bp: $132-135^{\circ} \mathrm{C} / 1 \mathrm{~mm}$ (lit., ${ }^{18}$ bp: $127-$ $\left.134^{\circ} \mathrm{C} / 1 \mathrm{~mm}\right) ;{ }^{1} \mathrm{H} \mathrm{NMR}\left(\mathrm{CDCl}_{3}, 300 \mathrm{MHz}\right): \delta 0.016(9 \mathrm{H}$, s), 1.0-2.35 (20H, complex multiplets), $2.98(1 \mathrm{H}, \mathrm{d}$, $J=2.7 \mathrm{~Hz}) ;{ }^{13} \mathrm{C} \mathrm{NMR}\left(\mathrm{CDCl}_{3}, 75 \mathrm{MHz}\right): \delta-4.3,19.6$, 20.0, 25.6, 54.1, 55.3.

\section{Acknowledgements}

A. S. thanks the Council of Scientific and Industrial Research, New Delhi for the grant of a Senior Research Fellowship.

\section{References}

1. Jorgenson, K. A. Chem. Rev. 1989, 89, 431.

2. Parshall, G. W.; Ittel, S. D.; 2nd ed. Homogenous Catalysis: The Applications and Chemistry of Catalysis by Soluble Transition Metal Complexes; Wiley: New York, 1992.

3. (a) Barton, D. H. R.; Martell, A. E.; Sawyer, D. T. The Activation of Dioxygen and Homogenous Catalytic Oxidation; Plenum: New York, 1993. (b) Lane, B. S.; Vogt, M.; Derose, V. J.; Burgess, K. J. Am. Chem. Soc. 2002, 124, 11946. (c) Herrman, W. A.; Fridgen, J.; Haider, J. J. Peroxide Chem. 2000, 406. (d) Hunter, R.; Turner, P.; Rimmer, S. Synth. Commun. 2000, 30, 4461. (e) Kim, G.; Shin, J. Catal. Lett. 1999, 63, 83 .

4. (a) Bennett, S.; Brown, S. M.; Conole, G.; Kessler, M.; 
Rowling, S.; Sinn, E.; Woodward, S. J. Chem. Soc., Dalton Trans. 1995, 367. (b) Goldstein, A. S.; Drago, R. S. J. Chem. Soc., Chem. Commun. 1991, 21. (c) Balavoine, G.; Eskenazi, C.; Meunier, F.; Rivière, H. Tetahedron Lett. 1984, 25, 3187. (d) Gross, Z.; Ini, S. Org. Lett. 1999, 1, 2077. (e) Dutta, S.; Bhattacharya, P. K. J. Mol. Catal. A: Chem. 2002, 188, 45. (f) Stoop, R. M.; Bachmann, S.; Valentini, M.; Mezzetti, A. Organometallics 2000, 19, 4117.

5. (a) Togni, A.; Venanzi, L. M. Angew. Chem. Int. Ed. Engl. 1994, 33, 497. (b) Barf, G. A.; VandenHoeki, D.; Sheldon, R. A. Tetrahedron 1996, 52, 12971. (c) End, N.; Pfaltz, A. Chem. Commun. 1998, 5, 589. (d) Cetinkaya, B.; Cetinkaya, E.; Brookhart, M.; White, P. S. J. Mol. Catal. 1999, 142, 101. (e) Pezet, F.; Ait-Haddon, H.; Daran, J.; Sasaki, I.; Balavoine, G. G. A. Chem. Commun. 2002, 5, 510.

6. (a) Kesavan, V.; Chandrasekaran, S. J. Chem. Soc., Perkin Trans. 1 1997, 3115. (b) Kesavan, V.; Chandrasekaran, S. J. Org. Chem. 1998, 63, 6999.

7. Colvin, E. W. Silicon Reagents in Organic Synthesis; Academic: New York, 1988.

8. Cuadrado, P.; González-Nogal, A. M. Tetrahedron Lett. 2000, 41, 1111.
9. Chan, T. H.; Chen, L. M.; Wang, D. J. Chem. Soc., Chem. Commun. 1988, 1280.

10. Chauret, D. C.; Chong, J. M. Tetrahedron Lett. 1993, 34, 3695.

11. Hudrlik, P. F.; Peterson, D.; Rona, R. J. J. Org. Chem. 1975, 40, 2263.

12. Nagendrappa, G. Synthesis 1980, 704.

13. Adam, W.; Prechtt, F.; Richter, M. J.; Smerz, A. K. Tetrahedron Lett. 1993, 34, 3695.

14. Nagendrappa, G.; Patil, G. S. J. Chem. Soc., Perkin 2 2001, 1099.

15. Kaneda, K.; Haruna, S.; Imanaka, T.; Hamamoto, M.; Nishiyama, Y.; Ishii, Y. Tetrahedron Lett. 1992, 33, 6827.

16. Groves, J. T.; Quinn, R. J. Am. Chem. Soc. 1985, 107, 5790.

17. Jackson, B. F. G.; Lewis, J.; Ryder, I. E. J. Chem. Soc. Dalton Trans. 1977, 719.

18. Nagendrappa, G.; Vidyapathi, J. J. Organomet. Chem. 1985, $280,31$.

19. Davies, A. P.; Hughes, G. J.; Lowndes, P. R.; Robbins, C. M.; Thomas, E. J.; Whitham, G. H. J. Chem. Soc., Perkin Trans. 1 1981, 1934.

20. Patil, G. S.; Nagendrappa, G. Indian J. Chem. 2002, 41B, 1019.

21. Arnaud, C.; Zakarya, D. J. Chem. Ed. 1986, 63, 1105. 